\title{
PERBEDAAN PRESTASI BELAJAR MATA PELAJARAN KEAGAMAAN ANTARA SANTRIWATI PROGRAM REGULER DAN PROGRAM INTENSIF KELAS V TMI PUTERI AL-AMIEN PRENDUAN
}

\author{
NURUL HUSNA YUSUF \\ Dosen Pendidikan Guru Madrasah Ibtidaiyah Fakultas Agama Islam \\ Universitas Muhammadiyah Palangkaraya \\ Email : noena_elbara@yahoo.com
}

\begin{abstract}
Departing from different educational backgrounds, the female students of the graduate SD/MI (regular program) and female students graduated from junior high school/MT (intensive program), then is there any difference in learning achievement are achieved mainly in religious subjects at grade students $V$. To the authors conduct research in TMI Princess Al-Amien Prenduan. As the population is female students of class $V 181$ students consisting of 67 students of the regular program and 114 students intensive program. The samples using random sampling techniques by means of a lottery that consists of 50 students of the regular program and 50 students of the intensive program. While the value of learning achievement is taken from the report cards of students who become documents in TMI institutions Princess Al-Amien Prenduan. Based on the analysis by using the formula $\mathrm{t}=\frac{\mathrm{M}_{\mathrm{X}} \mathrm{M}_{\mathbf{Y}}}{\mathrm{SD}_{\mathrm{b}}}$ can be seen that $t$ score (1.83) is smaller than the value $t$ in the table either from a level of $1 \%$ (2.62) as well as the confidence level of $5 \%$ (1.98). Thus Ho is accepted, meaning that there is no difference in learning achievement in the subjects of religion among female students and female students regular program intensive program class $V$.

The learning achievement santriwati regular program represented sample showed a mean value = 6.36, which means that the learning achievement of female students in the regular program of religious subjects including good enough category. While learning achievement santriwati intensive program showed a mean value $=5.94$ categorized enough. From the above results, it can be the authors mentioned that there was no significant difference between students' learning achievement and regular program students intensive courses in religious subjects.
\end{abstract}

Keywords : learning achievement, regular program, intensive program

\section{ABSTRAK}

Berangkat dari latar belakang pendidikan yang berbeda, yakni santriwati dari lulusan SD/MI (program reguler) dan santriwati lulusan SLTP/MTs (program intensif), maka adakah perbedaan prestasi belajar yang dicapai utamanya dalam mata pelajaran keagamaan pada santri kelas $V$. Untuk itu penulis mengadakan penelitian di TMI Puteri Al-Amien Prenduan. Sebagai populasi adalah santriwati kelas V sebanyak 181 santri yang terdiri dari 67 santri program regular dan 114 santri program intensif. Pengambilan sampel menggunakan teknik random sampling dengan cara undian yang terdiri dari 50 santri program regular dan 50 santri program intensif. Sedangkan nilai prestasi belajar diambil dari raport santri yang menjadi dokumen di lembaga TMI Puteri Al-Amien Prenduan. Berdasarkan hasil analisis dengan menggunakan rumus $\mathrm{t}=\frac{\mathrm{M}_{\mathrm{X}}-\mathrm{M}_{\mathrm{Y}}}{\mathrm{SD}_{\mathrm{b}}}$ dapat diketahui bahwa $\mathrm{t}$ score $(1,83)$ lebih kecil dari nilai $\mathrm{t}$ dalam table baik dari taraf kepercayaan $1 \%(2,62)$ maupun taraf kepercayaan $5 \%(1,98)$. Dengan demikian Ho diterima, yang berarti bahwa tidak ada perbedaan prestasi belajar dalam mata pelajaran keagamaan antara santriwati program reguler dan santriwati program intensif kelas $\mathrm{V}$.

Adapun prestasi belajar santriwati program regular yang diwakili sample menunjukkan nilai mean = 6.36, yang berarti bahwa prestasi belajar dari santriwati program regular dalam mata pelajaran keagamaan termasuk kategori cukup baik. Sedangkan prestasi belajar santriwati program intensif menunjukkan nilai mean $=5.94$ termasuk kategori cukup. Hasil ini menyebutkan bahwa tidak ada perbedaan yang signifikan antara prestasi belajar santriwati program regular dan program intensif dalam mata pelajaran keagamaan.

Kata kunci : prestasi belajar, program reguler, program intensif 


\section{PENDAHULUAN}

Pendidikan merupakan usaha sadar yang dilakukan oleh orang dewasa membawa anak kearah kedewasaan lahir batin. Sekolah, Madrasah, Pondok Pesantren suatu wadah dimana anak-anak diajar, dididik, dibimbing agar mereka memiliki pengetahuan, keterampilan, sikap, akhlak dan perilaku yang mulia.

Secara umum "Tujuan pendidikan di TMI AL-Amien Prenduan mengacu pada tujuan pendidikan nasional yang berlaku khususnya pada jenjang pendidikan lanjutan pertama dan menengah" (Jauhari : 24). Adapun tujuan Pendidikan Nasional menurut ketetapan MPR. RI. No.II/MPR/1998 dalam GBHN :

Pendidikan Nasional bertujuan untuk meningkatkan kualitas dari manusia Indonesia, yaitu manusia yang bertaqwa kepada Tuhan Yang Maha Esa, berbudi luhur, berkepribadian, mandiri, tangguh, cerdas, kreatif, serta Sehat Jasmani dan Rohani.

Adapun prestasi dalam bahasa Indonesia diartikan sebagai : "Hasil yang telah dicapai (dilakukan, dikerjakan dsb.)", (W.J.S Poerwadarminta, 1976 : 768).

Sebagaimana kita ketahui bahwa belajar adalah suatu aktivitas psikis/mental dalam interaksi dengan lingkungan yang diwujudkan dalam bentuk penguasaan ilmu pengetahuan, kecakapan, sikap, perilaku, nilai, keterampilan dan lain sebagainya yang sifatnya relatif menetap.

Prestasi belajar adalah merupakan suatu hasil usaha yang dilakukan dan dikerjakan dalam belajar, sebagaimana dikemukakan oleh Afifuddin (1988 : 112) bahwa : Prestasi belajar adalah keseluruhan hasil yang dicapai dalam suatu pelaksanaan proses belajar baik dalam bentuk penguasaan pengetahuan, kecakapan, keterampilan, kebiasaan, sikap, dalam waktu tertentu.

Moergadi (1987: 80) mengemukakan bahwa: "Prestasi belajar adalah kemampuan untuk mencapai hasil yang maksimal pada saat belajar, yang dicapai dalam kurun waktu tertentu".

Dari pendapat-pendapat tersebut ditarik kesimpulan bahwa prestasi belajar adalah hasil dari proses usaha dalam kegiatan belajar pada jangka waktu tertentu. Prestasi belajar biasanya dinyatakan dalam bentuk angka, huruf, pernyataan dan simbol-simbol yang lain.

Prestasi belajar yang dicapai tidak terlepas dari adanya beberapa faktor yang mempengaruhi baik dari dalam diri siswa atau dari luar.

Adapun jenjang studi yang harus ditempuh santri setelah lulus melalui tes masuk, yaitu santri lulusan SD/MI (yang kemudian disebut program reguler) akan menempuh jenjang pendidikan selama 6 tahun sampai kelas akhir (kelas 6), setiap jenjang ditempuh dalam jangka waktu 1 tahun. Sedangkan santri lulusan SLTP/MTs (Program Intensif) akan menempuh selama 4 tahun, sampai kelas akhir (Kelas 6) dengan perincian tahun pertama berada di kelas 1 intensif, tahun kedua duduk di kelas III intensif, tahun ketiga duduk dikelas $\mathrm{V}$ dan tahun keempat duduk di kelas akhir yakni kelas $\mathrm{VI}$

TMI Al-Amien Prenduan adalah lembaga pendidikan lanjutan pertama dan menengah yang berbasis dan berbentuk Pondok Pesantren dengan masa studi 6 tahun bagi lulusan SD/MI, 4 tahun bagi lulusan SLTP/MTs. Ditinjau dari jenjang pendidikannya dan masa studinya, TMI Al-Amien Prenduan setingkat dengan MTs dan MA atau SLTP dan SMU. 
Arah pendidikan di TMI Al-Amien Prenduan tidak semata-mata bersifat vertikal (untuk melanjutkan ke jenjang yang lebih tinggi), melainkan pula mempersiapkan santri untuk mampu terjun dalam masyarakat secara mandiri dengan mengamalkan dan mengembangkan "bekal-bekal dasar" yang diperoleh dan dimiliki para santri selama belajar di Pondok Pesantren.

Berangkat dari latar belakang pendidikan yang berbeda yakni santri dari lulusan SD/MI (Program Reguler) Dan santri lulusan SLTA/MA (Program Intensif), maka adakah prestasi belajar yang dicapai utamanya dalam mata pelajaran Keagamaan pada santri kelas 5 .

Mencari perbedaan hasil prestasi belajar bagi para santri dari kedua jenjang pendidikan yang berbeda, dan mengetahui rata-rata hasil prestasi belajar dari kedua program terutama untuk mata pelajaran Keagamaan. Mata pelajaran keagamaan dalam hal ini meliputi :

a. Ulum Tanziliyah (Dirosat Islamiyah) antara lain :

\section{Al-Qur'an Wa Ulumuhu}

2. Al-Hadist Wa Ulumuhu

3. Al- Fiqhu Wa Ulumuhu

4. Al-Aqoid Wal-Akhlaq Wat-Tashawuf

5. Sirah Nabawiyah Wat - Tarikh Hadharah Al - Islam (Sejak kelas 2 seluruh mata pelajaran tersebut disampaikan dengan pengantar berbahasa Arab)

b. Ulum Arabiyah, meliputi :

1. Al-Maharat Al Arobiyah

2. Al-Qowaid Al Arobiyah

3. Al-Adab Al Arobiyah

(Seluruh mata pelajaran tersebut disampaikan dengan pengantar berbahasa Arab).
Perlu diketahui bahwa program intrakurikuler (al-manhaj adz-Dzati) di TMI AlAmien Prenduan merupakan perpaduan yang integral antara kurikulum nasional dan kurikulum mua'limien yang dikemas dalam bentuk Garis garis Besar Program pendidikan (GBPP) dan dijabarkan dalam Rencana Induk Program Pendidikan (RIPP) yang meliputi 4 kelompok bidang studi, diantaranya :

a. Ulum Tanziliyah (Dirosat Islamiyah)

b. Ulum Arobiyah

c. Kurikulum Nasional

d. Ulum Tarbiyah Ma'hadiyah.

Jadi tujuan yang ingin dicapai dalam penelitian ini adalah :

1. Ingin mengetahui adanya perbedaan prestasi belajar mata pelajaran keagamaan antara santritiwa program reguler dan santriwati program intensif kelas V Al-Amien Prenduan.

2. Mengetahui tingkat keberhasilan meraih prestasi belajar dalam mata pelajaran keagamaan baik santriwati program reguler maupun program intensif kelas $\mathrm{V}$ Al-Amien Prenduan.

\section{METODOLOGI}

Metodologi dalam penelitian ini secara sederhana diartikan sebagai ajaran tentang metode yang digunakan dalam proses penelitian. Dalam penelitian ini yang dijadikan objek penelitian adalah TMI Puteri AI-Amien Prenduan. Adapun subjek yang diteliti adalah para santri kelas V.

Sesuai dengan tujuan maka data yang diperlukan adalah prestasi belajar dalam mata pelajaran keagamaan. Sebagai populasi adalah para santri kelas $\mathrm{V}$ sebanyak 181 yang terdiri dari 
67 santri program reguler dan 114 santri program intensif.

Pengambilan sampel menggunakan teknik random sampling dengan cara undian, yang terdiri dari 50 santri program reguler dan 50 santri program intensif.

Data nilai prestasi diambil dari rapor para santri atau dokumen yang ada di lembaga (TMI). Adapun dalam memperoleh suatu kesimpulan yang tepat dan benar diperlukan teknik analisis yang sesuai dengan tujuan.

Dalam penelitian ini peneliti menggunakan teknik analisis. Teknik analisis adalah suatu cara yang digunakan menganalisa data yang diperoleh untuk mengkaji kebenaran hipotesis. Jadi di sini penulis menggunakan 2 teknik analisis sesuai dengan hipotesis yang diajukan.

a. Untuk Hipotesis I : Bahwa tidak ada perbedaan yang signifikan antara hasil prestasi belajar dalam bidang keagamaan antara santriwati program reguler dan program intensif kelas V TMI Puteri Al-Amien Prenduan, penulis menganalisa dengan menggunakan rumus t-test seperti dibawah ini :

$t=\frac{M_{x} M_{y}}{S D_{b}}$

(Sutrisno Hadi, 1967; II/38)

Keterangan :

$\mathrm{t}=\mathrm{t}-$ Score

$\mathrm{M}_{\mathrm{x}}=$ Mean dari variabel $\mathrm{X}$

$\mathrm{M}_{\mathrm{y}}=$ Mean dari variabel $\mathrm{Y}$

$\mathrm{SD}_{\mathrm{b}}=$ Standar kesalahan Perbedaan Mean

Kemudian membandingkan nilai $\mathrm{t}$ yang diperoleh dengan nilai $t$ dalam tabel, untuk menentukan adanya perbedaan yang signifikan atau tidak. b. Untuk menganalisa hipotesis II bahwa: Ratarata hasil prestasi belajar dalam bidang keagamaan baik santriwati program reguler maupun santriwati program intensif kelas $\mathrm{V}$ termasuk dalam kategori "Baik", dengan cara mencari nilai rata-rata kelas tiap program studi dengan rumus masing-masing.

1. Untuk Program Reguler :

$$
\begin{aligned}
& M_{x}=\frac{\sum X}{N_{x}} \\
& M_{x}=\text { Mean dari variabel } X \\
& \Sigma X=\text { Jumlah nilai variabel } X \\
& N_{x}=\text { Jumlah subjek variabel } X
\end{aligned}
$$

2. Untuk Program Intensif

$$
\begin{aligned}
M_{y} & =\frac{\sum Y}{N_{y}} \\
M_{y} & =\text { Mean dari variabel } Y \\
\Sigma Y & =\text { Jumlah nilai variabel } Y \\
N_{y} & =\text { Jumlah subjek variabel } Y
\end{aligned}
$$

Kemudian hasilnya masing-masing dibandingkan dengan kriteria penilaian yang berlaku seperti dibawah ini :

$$
\begin{array}{ll}
9-10 & \text { : Baik Sekali } \\
7-8 & \text { : Baik } \\
5-6 & \text { : Cukup } \\
3-4 & \text { : Kurang } \\
1-2 & \text { : Kurang Sekali }
\end{array}
$$

Sesuai dengan sifat penelitian ini adalah dokumenter maka pengambilan data yang dibutuhkan ialah dengan mencatat dokumen (rapor) santriwati kelas V di TMI Puteri Al-Amien Prenduan. 
Sebagai tolak ukur dan bahan analisa, penulis melihat dan mencatat prestasi belajar mata pelajaran keagamaan santri kelas $\mathrm{V}$ santriwati program reguler dan santri program intensif. Data yang diperoleh sebagai bahan analisis.

Hipotesis yang paling sederhana setidaktidaknya dari segi teoritis adalah hipotesis nihil yang biasanya dinyatakan dengan Ho. Istilah nihil disini menunjukkan kepada tidak adanya perbedaan anatara sampel yang satu dengan yang lain dalam hal yang diselidiki. Dalam hal ini maka :

a. Hipotesis nihil diterima pada taraf signifikansi $5 \%$ atau $1 \%$ apabila $\mathrm{t}$-score yang diperoleh lebih kecil dari t-score dalam tabel.

b. Hipotesis nihil ditolak pada taraf signifikansi $5 \%$ atau $1 \%$ apabila $\mathrm{t}$-score yang diperoleh lebih besar dari t dalam tabel.

Untuk hipotesis II: Nilai rata-rata prestasi adalah "Baik" apabila rata-rata yang diperoleh adalah 6 ke atas.

\section{HASIL DAN PEMBAHASAN}

Atas bantuan para ustadzah peneliti dapat memperoleh data yang dibutuhkan yakni data prestasi belajar santriwati seluruh kelas 5 dalam bidang keagamaan. Sesuai dengan tujuan penelitian populasi dibagi menjadi dua sampel, masing masing 50 santriwati, santriwati program reguler dan santriwati program intensif, diambil secara acak(random) dengan cara undian.

Data yang diperoleh dianalisa dengan teknik statistik dalam bentuk Tabel 1. dan Tabel 2. Kemudian, untuk mengetahui adanya perbedaan prestasi belajar antara santri program reguler dan santri program intensif digunakan analisa statistik dengan tabel kerja pada Tabel 3.

Nilai t yang diperoleh dibandingkan dengan nilai t dalam tabel pada taraf kepercayaan $1 \%$ dan $5 \%$ dengan db $\mathrm{N}_{\mathrm{x}}+\mathrm{N}_{\mathrm{y}}-2$ diperoleh untuk taraf kepercayaan $1 \%=2,58$ untuk taraf kepercayaan $5 \%=1,96$ seperti nampak dalam Tabel 4 .

Tabel 4. Perbandingan nilai $\mathrm{t}$

\begin{tabular}{|c|c|c|c|}
\hline \multirow{3}{*}{$\mathrm{db}=98$} & \multirow{3}{*}{$t=1,83$} & \multicolumn{2}{|c|}{ Taraf Signifikansi } \\
\hline & & $1 \%$ & $5 \%$ \\
\hline & & 2,62 & 1,98 \\
\hline
\end{tabular}

Karena nilai $\mathrm{t}$ yang diperoleh $(1,83)$ lebih kecil dari nilai $t$ dalam tabel baik taraf kepercayaan $1 \% \quad(2,62)$ maupun taraf kepercayaan $5 \%(1,98)$ maka hipotesis nihil yang menyatakan bahwa : tidak ada perbedaan hasil prestasi belajar dalam bidang keagamaan antara santriwati program reguler dan santriwati program intensif diterima.

Perbedaan rata-rata nilai antara santriwati Program Reguler dan Program Intensif sebesar $4,2(63,6$ - 59,4) adalah suatu perbedaan yang kurang berarti.

Untuk membuktikan hipotesis bahwa ratarata prestasi belajar santriwati Program reguler dan santriwati intensif adalah "Baik" dengan mencari rata-rata nilai prestasi masing masing, kemudian membandingkan dengan kriteria penilaian.

\begin{tabular}{|lll|}
\multicolumn{2}{|c|}{ Kriteria Penilaian } \\
\hline $9-10$ & $:$ & Baik Sekali \\
$7-8$ & $\vdots$ & Baik \\
$5-6$ & $\vdots$ & Cukup \\
$3-4$ & $\vdots$ & Kurang \\
$1-2$ & $:$ & Kurang Sekali \\
\hline
\end{tabular}


Tabel 1. Distribusi Nilai Santriwati Program Reguler

\begin{tabular}{|c|c|c|c|c|c|c|c|c|c|c|c|c|}
\hline \multirow{2}{*}{ No } & \multirow{2}{*}{ Nama } & \multicolumn{5}{|c|}{ U. Tanziliyah } & \multirow{2}{*}{$\begin{array}{l}\text { Rata } \\
\text { rata }\end{array}$} & \multicolumn{3}{|c|}{ B. Arab } & \multirow{2}{*}{$\begin{array}{l}\text { Rata } \\
\text { rata }\end{array}$} & \multirow{2}{*}{$\begin{array}{l}\text { Rata } \\
\text { rata } \\
\text { Nilai }\end{array}$} \\
\hline & & 1 & 2 & 3 & 4 & 5 & & $a$ & $\mathbf{b}$ & C & & \\
\hline 1 & Kholifah. I & 7 & 6,5 & 7,5 & 6,5 & 5,5 & 6,6 & 7 & 7 & 6 & 6,66 & 6,6 \\
\hline 2 & Kiki Rizki. A & 7 & 8 & 8,5 & 8 & 7,5 & 7,8 & 8,5 & 8 & 8 & 8,12 & 8,0 \\
\hline 3 & Merry. S & 8 & 8,5 & 9 & 8,5 & 8 & 8,4 & 8,5 & 8,5 & 9 & 8,66 & 8,5 \\
\hline 4 & Faizatul. A & 8 & 9 & 9 & 8 & 7,5 & 8,3 & 8,5 & 8,5 & 9 & 8,66 & 8,5 \\
\hline 5 & Daniatul. K & 8 & 9 & 9 & 8,5 & 8,5 & 8,6 & 7 & 8 & 8,5 & 7,83 & 8,2 \\
\hline 6 & Dwi Fajarwati & 7 & 7,5 & 7,5 & 6 & 4,5 & 6,5 & 7 & 7 & 8,5 & 7,50 & 7,0 \\
\hline 7 & Darul Hikmah & 7,5 & 8 & 8 & 8,5 & 7 & 7,8 & 7 & 8,5 & 7,5 & 7,22 & 7,5 \\
\hline 8 & Evi Munawaroh & 7 & 7,5 & 8 & 7,5 & 7 & 7,4 & 8 & 6 & 8 & 7,33 & 7,4 \\
\hline 9 & Etik Kartila & 8 & 9 & 8 & 8,5 & 7 & 8,1 & 8 & 9 & 8,5 & 8,50 & 8,3 \\
\hline 10 & Evi Kurniati & 7,5 & 7,5 & 7 & 8,5 & 6 & 7,3 & 8 & 9 & 8 & 8,33 & 7,8 \\
\hline 11 & Miftahul KH & 7 & 9 & 8,5 & 8 & 6 & 7,7 & 5 & 6,5 & 8 & 6,50 & 7,1 \\
\hline 12 & Lailatul. M & 6,5 & 7 & 7 & 6,5 & 6,5 & 6,7 & 5,5 & 6,5 & 5 & 5,66 & 6,2 \\
\hline 13 & ST. Fatonah & 6,5 & 6,5 & 7,5 & 9 & 6,5 & 7,2 & 5 & 7,5 & 7,5 & 6,66 & 6,9 \\
\hline 14 & Mamik. M & 8 & 7 & 9 & 5,5 & 5,5 & 7,1 & 6,5 & 8 & 8 & 7,50 & 7,3 \\
\hline 15 & Farah. M & 8 & 7 & 7,5 & 7,5 & 5 & 7 & 6,0 & 6 & 8,5 & 6,80 & 6,9 \\
\hline 16 & Evi Lis. $\mathrm{S}$ & 7 & 6,5 & 8 & 4,5 & 4 & 6 & 4,5 & 4,5 & 6 & 5,00 & 5,5 \\
\hline 17 & Tilkal Jannah & 8 & 7 & 9 & 6,5 & 6 & 7,3 & 5,5 & 8 & 8,5 & 7,30 & 7,3 \\
\hline 18 & Zahratul. M & 6 & 6,5 & 7,5 & 4 & 5 & 5,6 & 5,0 & 5 & 7 & 5,60 & 5,6 \\
\hline 19 & Rusdiyah & 8 & 7 & 9 & 5 & 6,5 & 7,1 & 6,0 & 5,5 & 9 & 6,80 & 7,0 \\
\hline 20 & Elliyana & 8 & 7 & 9 & 4,5 & 8 & 7,3 & 4,5 & 6 & 7 & 5,83 & 6,6 \\
\hline 21 & Makkiyah. M & 5,5 & 4 & 7,5 & 6 & 7 & 6 & 4 & 7,5 & 6 & 5,80 & 5,9 \\
\hline 22 & Ryan Yulita & 5,5 & 3,5 & 8,5 & 6,5 & 7 & 6,2 & 2 & 7,5 & 5,5 & 5,00 & 5,6 \\
\hline 23 & Eva UI. A & 9 & 6 & 7,5 & 8,5 & 8 & 7,9 & 4,5 & 8 & 5 & 6,00 & 7,0 \\
\hline 24 & Nida Diana & 9 & 4,5 & 7,5 & 8 & 7,5 & 7,3 & 4 & 6,5 & 4,5 & 5,00 & 6,2 \\
\hline 25 & Rizkiyatul. K & 9 & 5,5 & 8 & 7,5 & 6,5 & 7,3 & 5,5 & 7,5 & 6,5 & 6,50 & 6,9 \\
\hline 26 & ST. Sumarliya. R & 9 & 5,5 & 9 & 7,5 & 5,5 & 7,3 & 6,5 & 9 & 7 & 7,5 & 7,4 \\
\hline 27 & Rohmatus. SH & 9 & 5 & 8,5 & 8 & 6 & 7,3 & 6,5 & 9 & 7,5 & 7,60 & 7,5 \\
\hline 28 & Listiani & 8 & 6,5 & 8 & 7 & 7 & 7,3 & 4 & 8,5 & 4,5 & 5,66 & 6,5 \\
\hline 29 & Luluk Fitrotin & 7 & 4,5 & 6,5 & 8 & 8,5 & 6,9 & 4,5 & 6,5 & 4,5 & 5,12 & 6,0 \\
\hline 30 & Fikri A. R & 6,5 & 4,5 & 7,5 & 7 & 5 & 6,1 & 3,5 & 7 & 5,5 & 5,33 & 5,7 \\
\hline 31 & Dian Shofia & 6 & 4 & 5,5 & 7 & 6 & 5,7 & 3,5 & 7 & 3,5 & 4,66 & 5,2 \\
\hline 32 & Alwiyah. D & 2,5 & 4,5 & 3 & 4,5 & 3,5 & 3,6 & 5 & 2,5 & 3 & 3,50 & 3,6 \\
\hline 33 & Fibriyani. R & 6,5 & 4,5 & 6 & 6,5 & 5,5 & 5,8 & 4 & 7 & 4 & 5,00 & 5,4 \\
\hline 34 & Qurratul A.H & 6,5 & 6 & 7 & 7 & 5,5 & 6,4 & 3,5 & 8,5 & 5 & 5,66 & 6,0 \\
\hline 35 & Riska Amalia & 6 & 3,5 & 7 & 7 & 7 & 6,1 & 4 & 6,5 & 4,5 & 5,00 & 5,6 \\
\hline 36 & Ririn J & 5,5 & 3 & 6,5 & 7 & 8 & 6,0 & 4 & 9 & 4,5 & 5,83 & 5,9 \\
\hline 37 & ST. Rofiqoh & 6,5 & 5,5 & 6,5 & 7,5 & 6,5 & 6,5 & 5 & 7,5 & 6 & 6,16 & 6,3 \\
\hline 38 & Sholihatin. M & 6,5 & 4 & 5 & 7 & 5 & 5,5 & 5,5 & 7,5 & 5,5 & 6,16 & 5,8 \\
\hline 39 & Ida Laili. S & 6,5 & 3,5 & 6,5 & 6,5 & 7,5 & 6,1 & 5,5 & 7,5 & 7,5 & 6,83 & 6,5 \\
\hline 40 & Ira Andriani & 7 & 4,5 & 6 & 7,5 & 6 & 6,2 & 3 & 7 & 3,5 & 5,33 & 5,8 \\
\hline 41 & Erna Kartika & 8 & 4 & 4,5 & 6 & 4,5 & 5,4 & 4 & 7 & 3,5 & 4,83 & 5,1 \\
\hline 42 & Eyis. R & 6,5 & 3,5 & 6,5 & 7,5 & 6 & 6,0 & 3,5 & 7 & 6 & 5,50 & 5,8 \\
\hline 43 & Husnul Fajariah & 7 & 3,5 & 6 & 7 & 6 & 5,9 & 3,5 & 4 & 2 & 3,12 & 4,5 \\
\hline 44 & Ika Susilawati & 3 & 6 & 4,5 & 6 & 7 & 5,3 & 3 & 4 & 2 & 3,00 & 4,2 \\
\hline 45 & ST. Aisyah. Q & 1 & 4,5 & 4,5 & 6 & 7,5 & 4,7 & 3 & 4 & 2,5 & 3,12 & 3,9 \\
\hline 46 & Musfita KH & 3 & 4 & 5 & 5,5 & 5,5 & 4,6 & 3,5 & 5 & 3,5 & 4,00 & 4,3 \\
\hline 47 & Nur Syamsiyah & 3 & 3,5 & 6 & 6 & 5 & 4,7 & 4 & 6 & 7 & 5,66 & 5,2 \\
\hline 48 & Lailatus Sulfiyah & 8,5 & 4 & 7,5 & 8 & 8,5 & 7,3 & 3,5 & 8,5 & 7,5 & 6,50 & 6,9 \\
\hline 49 & Maryam Jamilah & 6 & 6 & 7,5 & 2,5 & 6,5 & 5,7 & 4,5 & 6,5 & 5 & 5,3 & 5,5 \\
\hline 50 & Asri Barikoh & 7 & 7,5 & 8 & 5 & 5,5 & 6,6 & 5,5 & 7,5 & 1 & 6,66 & 6,6 \\
\hline
\end{tabular}

Sumber data : TMI Puteri Al-Amien Prenduan 
Tabel 2. Distribusi Nilai Santriwati Program Intensif

\begin{tabular}{|c|c|c|c|c|c|c|c|c|c|c|c|c|}
\hline \multirow[b]{2}{*}{ No. } & \multirow{2}{*}{ Nama } & \multicolumn{5}{|c|}{ U. Tanziliyah } & \multirow{2}{*}{$\begin{array}{l}\text { Rata } \\
\text { rata }\end{array}$} & \multicolumn{3}{|c|}{ B. Arab } & \multirow{2}{*}{$\begin{array}{l}\text { Rata } \\
\text { rata }\end{array}$} & \multirow{2}{*}{$\begin{array}{l}\text { Rata } \\
\text { rata } \\
\text { Nilai }\end{array}$} \\
\hline & & 1 & 2 & 3 & 4 & 5 & & a & b & c & & \\
\hline 1 & Musyarrofah & 7 & 8,5 & 8,5 & 8,5 & 6 & 7,7 & 7,5 & 6,5 & 7,5 & 7,12 & 7,4 \\
\hline 2 & Husnul Kh. S & 6,5 & 8 & 8 & 7 & 6 & 7,1 & 6 & 7 & 7 & 6,66 & 6,7 \\
\hline 3 & Hasnah & 7 & 7 & 8 & 6,5 & 6,5 & 7,0 & 6,5 & 7 & 7,5 & 7,00 & 7,0 \\
\hline 4 & Ervin $\mathrm{Y}$ & 6,5 & 9 & 8,5 & 3,5 & 5 & 6,5 & 5 & 6,5 & 5 & 5,50 & 6,0 \\
\hline 5 & Uswatun Hasanah & 7 & 7,5 & 8 & 8,5 & 9 & 8,0 & 6 & 7 & 9 & 7,33 & 7,7 \\
\hline 6 & Ummi Zakiyah & 8 & 8,5 & 8 & 7 & 6,5 & 7,6 & 8 & 7 & 9 & 8,00 & 7,8 \\
\hline 7 & ST. Marlia & 7 & 6 & 7 & 7 & 5 & 6,4 & 6 & 7,5 & 8 & 7,12 & 6,8 \\
\hline 8 & Ihda Khromy & 8 & 9 & 9 & 8 & 6,5 & 7,1 & 8 & 9 & 9 & 8,66 & 7,9 \\
\hline 9 & Lailatul Q & 8 & 8 & 8,5 & 7,5 & 5 & 7,4 & 6 & 7,5 & 8 & 7,12 & 7,3 \\
\hline 10 & Farah F. U & 6,5 & 6,5 & 7 & 8,5 & 6,5 & 7,0 & 5 & 4,5 & 5,5 & 5,00 & 6,0 \\
\hline 11 & Farah Dila. A & 6,5 & 6,5 & 6,5 & 7,5 & 7 & 6,8 & 4,5 & 7 & 8 & 6,50 & 6,7 \\
\hline 12 & Farika D. Y & 7 & 7 & 8,5 & 9 & 6,5 & 7,2 & 5,5 & 5 & 8 & 6,16 & 6,7 \\
\hline 13 & Azizah. I & 7,5 & 8 & 6,5 & 6 & 6,5 & 6,9 & 5,5 & 6,5 & 6,5 & 6,12 & 6,5 \\
\hline 14 & Utami N & 7,5 & 8,5 & 6,5 & 8 & 7,5 & 7,6 & 5 & 8 & 7 & 6,66 & 7,1 \\
\hline 15 & Najah H & 7,5 & 7 & 7,5 & 7 & 6 & 7,0 & 4,5 & 6,5 & 7 & 6,00 & 6,5 \\
\hline 16 & Nurhasanah M & 7 & 6,5 & 7,5 & 9 & 4 & 6,8 & 5,5 & 7,5 & 8 & 7,00 & 6,9 \\
\hline 17 & Rizkiyah & 6,5 & 6,5 & 8 & 8 & 7,5 & 7,3 & 4,5 & 5,5 & 7 & 5,66 & 6,5 \\
\hline 18 & Lin Sakinah & 6,5 & 6,5 & 7,5 & 7 & 5 & 6,5 & 6 & 6,5 & 7,5 & 6,66 & 6,6 \\
\hline 19 & Minarti & 5 & 6 & 8 & 5 & 4,5 & 5,7 & 5 & 5,5 & 6 & 5,50 & 5,6 \\
\hline 20 & Machdiatul I & 8 & 7,5 & 8,5 & 4,5 & 4,5 & 6,4 & 6,5 & 5,5 & 8,5 & 6,80 & 6,6 \\
\hline 21 & Hosnaini & 8 & 7 & 8,5 & 4,5 & 5,5 & 6,7 & 4 & 6 & 8 & 6,00 & 6,4 \\
\hline 22 & Atiqotul $\mathrm{H}$ & 6 & 5,5 & 7,5 & 2 & 4 & 4,8 & 6 & 7,5 & 5,5 & 6,30 & 6,0 \\
\hline 23 & Sulastri A & 6 & 5 & 8,5 & 7 & 5 & 6,3 & 4 & 5,5 & 8 & 5,80 & 6,0 \\
\hline 24 & Izzat Samhati & 5 & 6 & 7 & 2 & 5,5 & 5,1 & 5 & 4,5 & 7 & 5,50 & 5,3 \\
\hline 25 & Iradatul A & 7 & 6,5 & 8,5 & 3 & 4,5 & 5,9 & 4 & 4,5 & 6 & 4,80 & 5,4 \\
\hline 26 & Masruroh & 5,5 & 3,5 & 7,5 & 8,5 & 9 & 6,8 & 3,5 & 7 & 5 & 5,10 & 6,0 \\
\hline 27 & Faridatul M & 5 & 2,5 & 4 & 6 & 4 & 4,3 & 2,5 & 5,5 & 1,5 & 4,00 & 4,0 \\
\hline 28 & Choziyah & 9 & 5,5 & 7 & 7 & 5,5 & 6,8 & 4 & 9 & 4,5 & 5,80 & 6,0 \\
\hline 29 & Trisnawati & 6,5 & 6 & 2,5 & 7 & 7 & 6,6 & 4,5 & 8 & 7 & 6,5 & 6,5 \\
\hline 30 & Ummu Salamah & 5,5 & 4,5 & 6,5 & 7 & 6 & 5,9 & 5 & 7,5 & 4,5 & 5,60 & 6,0 \\
\hline 31 & Siti Juwairiyah & 7,5 & 5,5 & 7,5 & 7 & 6,5 & 6,7 & 4 & 7,5 & 7 & 6,10 & 6,4 \\
\hline 32 & Siti Aisyah & 9 & 6,5 & 8 & 8 & 8,5 & 8,0 & 5 & 9 & 7 & 7,00 & 7,5 \\
\hline 33 & Sherly H & 9 & 3,5 & 7 & 8,5 & 6 & 6,8 & 3 & 7,5 & 5 & 5,10 & 6,0 \\
\hline 34 & Syofiyah R & 7 & 3,5 & 6,5 & 6 & 5 & 5,6 & 3 & 7,5 & 3,5 & 5,30 & 5,5 \\
\hline 35 & Indah Wahyuni & 2,5 & 5 & 5,5 & 4,5 & 7 & 4,9 & 6 & 3,5 & 6,5 & 5,30 & 5,1 \\
\hline 36 & Khalisatun & 6 & 4 & 5,5 & 7 & 5,5 & 5,2 & 4 & 5,5 & 5 & 4,33 & 4,5 \\
\hline 37 & Dina Isniati & 6 & 3,5 & 5,5 & 7 & 5 & 5,4 & 4 & 6 & 4,5 & 4,83 & 5,1 \\
\hline 38 & Abidatul M & 5,5 & 5,5 & 6,5 & 7 & 7 & 6,2 & 4 & 7,5 & 4,5 & 5,33 & 5,5 \\
\hline 39 & Nur Fitriah H & 6 & 4 & 5 & 6,5 & 6 & 5,5 & 3,5 & 6 & 4,5 & 5,00 & 5,3 \\
\hline 40 & Nur Imamah A & 6 & 4 & 6,5 & 7 & 7 & 6,1 & 4,5 & 7 & 4,5 & 5,33 & 5,7 \\
\hline 41 & Rima Kr & 5,5 & 3 & 5,5 & 7 & 6,5 & 5,5 & 3,5 & 7,5 & 4,5 & 5,16 & 5,3 \\
\hline 42 & Roymillatia & 6,5 & 3,5 & 5 & 7 & 6,5 & 5,7 & 3,5 & 7,5 & 3,5 & 4,66 & 5,2 \\
\hline 43 & Nani Hartati & 4 & 3 & 5 & 6 & 7 & 5,0 & 3 & 6 & 4 & 4,66 & 4,8 \\
\hline 44 & Ratna N & 2,5 & 5,5 & 4,5 & 5,5 & 7 & 5,0 & 3 & 4,5 & 3,5 & 3,66 & 4,3 \\
\hline 45 & Dina Maryani & 2,5 & 5,5 & 4 & 6 & 8 & 5,2 & 4 & 4,5 & 6 & 4,82 & 5,0 \\
\hline 46 & Dhorifatun N & 2,5 & 5 & 5 & 6 & 6 & 4,9 & 2,5 & 3,5 & 2,5 & 2,83 & 3,9 \\
\hline 47 & Istiqomah S & 3 & 4,5 & 4,5 & 5,5 & 6 & 4,7 & 3 & 4,5 & 1 & 2,83 & 3,8 \\
\hline 48 & Nur Eva P & 2,5 & 4,5 & 5,5 & 6 & 5,5 & 4,8 & 3 & 4 & 2 & 3,00 & 3,9 \\
\hline 49 & Sherly M & 3,5 & 4,5 & 5 & 6,5 & 6 & 5,1 & 3 & 5,5 & 2 & 3,5 & 4,3 \\
\hline 50 & Siti Sunnatil M & 2,5 & 4 & 4,5 & 6,5 & 6,5 & 4,8 & 3,5 & 4,5 & 3 & 3,66 & 4,2 \\
\hline
\end{tabular}

Sumber Data : TMI Puteri Al-Amien Prenduan 
Tabel 3. Kerja mencari adanya perbedaan dua variabel antara program reguler dan program intensif

\begin{tabular}{|c|c|c|c|c|c|c|c|c|}
\hline \multirow{2}{*}{$\begin{array}{c}\text { Interval } \\
\text { Nilai }\end{array}$} & \multicolumn{4}{|c|}{ Nilai Program Reguler } & \multicolumn{4}{c|}{ Nilai Program Intensif } \\
\cline { 2 - 8 } & $\mathbf{X}$ & $\mathbf{F}$ & $\mathbf{f x}$ & $\mathbf{f x}^{2}$ & $\mathbf{Y}$ & $\mathbf{f}$ & $\mathbf{f x}$ & $\mathbf{f x}^{2}$ \\
\hline $85-89$ & 87 & 2 & 174 & 15138 & 87 & 0 & 0 & 0 \\
$80-84$ & 82 & 3 & 246 & 20172 & 82 & 0 & 0 & 0 \\
$75-79$ & 77 & 3 & 231 & 17787 & 77 & 4 & 308 & 23716 \\
$70-74$ & 72 & 8 & 576 & 41472 & 72 & 4 & 288 & 20736 \\
$65-69$ & 67 & 9 & 603 & 40401 & 67 & 11 & 737 & 49379 \\
$60-64$ & 62 & 5 & 310 & 19220 & 62 & 10 & 620 & 38440 \\
$55-59$ & 57 & 11 & 627 & 35739 & 57 & 4 & 228 & 12996 \\
$50-54$ & 52 & 4 & 208 & 10816 & 52 & 8 & 416 & 21632 \\
$45-49$ & 47 & 1 & 47 & 2209 & 47 & 2 & 94 & 4418 \\
$40-44$ & 42 & 2 & 84 & 3528 & 42 & 4 & 168 & 7056 \\
$35-39$ & 37 & 2 & 74 & 2738 & 37 & 3 & 111 & 4107 \\
$30-34$ & 32 & 0 & 0 & 0 & 32 & 0 & 0 & 0 \\
\hline
\end{tabular}

$$
\begin{aligned}
\mathrm{M}_{\mathrm{x}}= & \frac{\sum \mathrm{fX}}{\mathrm{N}_{\mathrm{x}}}=\frac{3180}{50}=63,6 \\
\mathrm{SD}_{\mathrm{x}}^{2} & =\frac{\sum \mathrm{fX}^{2}}{\mathrm{~N}_{\mathrm{x}}} \mathrm{M}_{\mathrm{x}}^{2} \\
& =\frac{209220}{50} \quad 63,6^{2} \\
& =4184,4-4044,96 \\
& =139,44 \\
\mathrm{SD}_{\mathrm{M}_{\mathrm{X}}}^{2} & =\frac{\mathrm{SD}_{\mathrm{X}}^{2}}{\mathrm{~N}_{\mathrm{x}} 1}=\frac{139,44}{50 \quad 1} \\
& =\frac{139,44}{49}=2,85
\end{aligned}
$$$$
\mathrm{M}_{\mathrm{y}}=\frac{\sum \mathrm{fY}}{\mathrm{N}_{\mathrm{y}}}=\frac{2970}{50}=59,4
$$$$
\mathrm{SD}_{\mathrm{y}}^{2}=\frac{\sum \mathrm{f} \mathrm{Y}^{2}}{\mathrm{~N}_{\mathrm{y}}} \mathrm{M}_{\mathrm{y}}^{2}
$$$$
=\frac{182480}{50} 59,4^{2}
$$$$
=3649,6-3528,36
$$

$$
\begin{aligned}
& =121,24 \\
\mathrm{SD}_{\mathrm{M}_{\mathrm{y}}}^{2} & =\frac{\mathrm{SD}_{\mathrm{x}}^{2}}{\mathrm{~N}_{\mathrm{y}} 1}=\frac{121,24}{501} \\
& =\frac{121,24}{49}=2,47
\end{aligned}
$$

$$
\begin{aligned}
\mathrm{SD}_{\mathrm{b}} & =\sqrt{\mathrm{SD}_{\mathrm{M}_{\mathrm{x}}}^{2}+\mathrm{SD}_{\mathrm{M}_{\mathrm{y}}}^{2}} \\
& =\sqrt{2,85+2,47} \\
& =\sqrt{5,32} \\
& =2,3 \\
\mathrm{t} & =\frac{\mathrm{M}_{\mathrm{x}} \quad \mathrm{M}_{\mathrm{y}}}{\mathrm{SD}_{\mathrm{b}}} \\
& =\frac{63,6 \quad 59,4}{2,3} \\
& =\frac{4,2}{2,3}=1,83
\end{aligned}
$$


a. Nilai rata-rata prestasi belajar santriwati Program Reguler $M_{X}=\frac{\sum f X}{N}=\frac{3180}{50}=63,6$ $(6,36)$. Nilai 6,36 termasuk dalam kategori "Cukup Baik"

b. Nilai rata-rata Prestasi Belajar santri Program Intensif adalah $\quad M_{y}=\frac{\sum f Y}{N}=\frac{2970}{50}=59,4$ $(5,94)$. Nilai 5,94 termasuk dalam kategori "Cukup".

\section{KESIMPULAN}

Berdasarkan hasil analisa dapat ditarik kesimpulan:

1. Tidak ada perbedaan yang signifikan antara prestasi belajar santriwati program reguler dan santriwati program intensif.

2. Nilai rata-rata prestasi belajar untuk program reguler 6,36 termasuk dalam kategori "Cukup baik", dan untuk program intensif berada dibawahnya, yakni 5,94 termasuk dalam kategori "Cukup". Adapun perbedaan nilai sebesar 0,42 adalah suatu perbedaan yang kurang berarti.

Dapat diinterpretasikan bahwa keberhasilan dalam pembelajaran dipengaruhi beberapa faktor:

1. Faktor Internal, yakni suatu potensi yang ada dalam diri anak, kemampuan intelegensi, minat, kemauan, dan motivasi diri dalam meraih prestasi. Karena itu perlu bantuan orang lain di luar dirinya untuk memotivasi dalam hal ini orang tua maupun guru.

2. Faktor Eksternal, yakni faktor di luar diri anak termasuk orang tua, guru, pendidik, pembimbing, pembina dan lain sebagainya. Begitu pula lingkungan di mana anak hidup bertempat tinggal, teman sepergaulan sangat mempengaruhi perkembangan dan pertumbuhan anak secara fisik dan mental.

\section{DAFTAR PUSTAKA}

Arief, Sukardi Sadiman, dkk. Beberapa Aspek Pengembangan Sumber Belajar. (Jakarta: Gema Insani Press, 2012).

Djamarah, Syaiful Bahri., Prestasi Belajar dan Kompetisi Guru. (Surabaya: Usaha Nasional, 1998).

Dimyati, Mudjiono. Belajar dan Pembelajaran. (Jakarta: Rineka Cipta, 1994).

Hadi, Sutrisno. Metodology Research II, III, (Jogyakarta: UGM, 1988).

Jauhari, Moh Idris. Belajar Efektif dan Efisien Bagaimana? (Prenduan: al-Amien Printing, 2004).

Jauhari, Moh Idris. TMI (Tarbiyatul Mua'limin AlIslamiyah), Apa,siapa, mana, kapan, bagaimana dan mengapa ?. (Prenduan: AlAmien Printing, $\mathrm{tt}$ ).

Jauhari, Moh Idris. Hakekat Pesantren dan Kunci Sukses Belajar di Dalamnya. (Prenduan: Al-Amien Printing, tt).

Purwanto, Halim. Psikologi Pendidikan. (Bandung: PT. Remaja Rosda Karya, 2000).

Purwadarminto, WJS. Kamus Bahasa Indonesia. (Jakarta: Balai Pustaka, 1976).

Sadiman, A.M. Interaksi dan Motivasi Mengajar. (Jakarta: PT. Raja Grafindo Persada, 2001).

Syah, Muhibbin. Psikologi Belajar. (Jakarta: PT. Grafindo Persada, 2003).

Sugiono. Belajar dan Pembelajaran. (Surabaya: Depdikbud IKIP Surabaya, 2000).

Usman, Uzer. Menjadi Guru Profesional. (Bandung: PT. Remaja Rosda Karya, 2000). 